\title{
Application of RBV Concepts in Implementing Strategy of Jordanian Higher Education
}

\author{
Zead M. Alhawamdeh ${ }^{1}$, Nayef Raji Alomyan ${ }^{2}$ \\ ${ }^{1}$ Faculty of Economics and Administrative Sciences, Jerash University, Jordan \\ Correspondence: Nayef Raji Alomyan, Faculty of Economics and Administrative Sciences, Jerash University, \\ Jordan.
}

Received: May 20, 2019

doi:10.5539/ibr.v12n7p96
Accepted: June 10, $2019 \quad$ Online Published: June 18, 2019

URL: https://doi.org/10.5539/ibr.v12n7p96

\begin{abstract}
This study chose Porter's (1980) conceptualization of competitive strategy, since this conceptualization is academically well accepted and internally consistent (Dess and Davis, 1984). Porter (1980) identified two generic ways in which an organization can gain sustainable competitive advantage over other firms in the industry: 'low cost' and 'differentiation'. A 'low-cost' strategy emphasizes the need to be the low-cost producer in the industry. A 'differentiation' strategy is based on creating and offering a product that is perceived industry-wide as unique
\end{abstract}

Keywords: high education, competitive strategy, strategic resources, marketing completion

\section{Introduction}

The focus of universities on the RBV approach to CA is evident in the work of Dyson (2004) who linked resource-based planning to SWOT analysis techniques, embedding it the competitive strategic planning processes at the University of Warwick, and illustrating it as an iterative process rather than a linear one. Also proponents of the RBV approach stressed the importance of a location asset in attracting postgraduate students; Hicks (2012) outlined the current value and inherent pitfalls of property investments of higher education institutions; Rood (2006) discussed elements of recruitment of top academic researchers in building brand image; and Lane (2006) observed the growing presence of universities in bond markets.

In conclusion, it can be observed that there is an increasing systematic adaptation of strategic management and competitive strategy more specifically by universities all over the world, and this stems from the realization that both domestic and global influence of globalization has increased the rate of direct and indirect competition among universities locally and internationally. The next section of the research work will detail the methodology which will form the basis for observing and analyzing the competitive strategies employed by Jordanian universities in relation to their foreign counterparts- the main focus of this thesis work.

\subsection{Problem Statement}

There is lack of prior research focused on understanding the patterns and types of competitive strategies which universities in Jordan use to cope with the intensifying rate of local and global competition in the higher education sector; as prior research has only focused on studying this phenomenon in the higher education sectors.

\subsection{Objectives of the Study}

The major aim of this research is to study the underlying implications of increasing competition, on Jordanian universities and to understand the repertoire of competitive strategies they have adopted over the years, from a resource based view perspective and the relationship between these strategies and the observable performance of the universities under study. More specifically, the research aims (a) to examine, identify and evaluate the repertoire of strategies developed by universities in their response to the increasing competitive nature of the environment; and (b) to understand which concept-based framework is best suited for competitive strategy formulation and implementation among private universities in Jordan.

\subsection{Significance of the Study}

Evidence pointing to the significance of this study mostly lies in the increasing degree of importance, relevance 
and attention given to issues of competition as contained in the strategic statements of universities. A review of the mission and vision statements of these universities reveal a lot of concern for their competitive positions relative to domestic and international competitors in the education sector.

The above excerpt is proof of the increasing attention being paid to competition among the private universities operating in Jordan and the Middle Eastern region in general. Thus it is clear that existing private universities have been able to operate effectively through the formulation and adoption of certain distinct strategies. According to Cooper \& Wade, (2005) these strategies generally describe the encompassing direction in which the institution is headed, determines appropriate resource allocation, as well as the provision of the underlying logic for the effective integration of the core interests of the different academic, and administrative units within the institutions.

In his study of the higher education market, Pick (2006) noticed that "universities are currently becoming business competitors in a global higher education market. Complex forces of government policies and broader social and economic events have combined to create a difficult terrain through which universities must now plot a course". In its aim of understanding the existing competitive strategies of the private universities operating in the Jordanian higher education sector, this research relies upon previous studies and investigations carried out on university competitive strategy, its management and strategic decision-making. Some of these previous research works includes but are not limited to the works of Anderson et al. (1999) whose work examined the contents of the publicly available strategic plans of universities to assess their development, application, and to suggest best practices. Also we rely on the work of Coaldrake and Stedman (1998) whose work analyzed and evaluated the existing circumstances of the higher education environment both competition wise and other wise, at the end of the 20th century and they concluded that most universities were still finding it difficult to adapt to an environment that has witnessed and is witnessing a lot of changes. Also the works of Marginson and Considine (2000) revealed the existence of an immense inadequacy in the common occurrences and in the existing governance models which were supposed to have come about in a bid to enable universities survive and exist in the current higher education environment. Finally, we rely on the work of Meek and Wood (2001) whose work evaluated the existing governance and management practices in the ever increasingly competitive higher education industry.

the higher education sector has recorded significant increases in numbers as well as diversity of programs offered; with the government taking the lead in this vital sector. In fact the government owned and subsidized all universities in Jordan up until the late 80s. The advent of private universities was mainly due to the rapid increase in the number of students enrolling into the existing government universities, and the resulting decline in quality of education offered by those universities due to lack of sufficient government funding. Thus the entrepreneurial establishment of private universities on the one hand relieved the government of the burden of providing education to the teeming number of students and making profit in the process on the other hand.

\subsection{Research Questions}

Now that it is clear that there is and has been an increasing rate of higher education competition both domestically and internationally, as stated earlier on, this research work aims to understand the competitive strategies which private universities in Jordan has adapted in the past and present, to survive in their peculiar environment (from a resource based view perspective). To achieve this, this proposed thesis poses two research questions. They are:

Research Question 1: What individual competitive strategies have the private universities in Jordan adopted to meet the increasing rate of competition within the domestic and global higher education sector?

Research Question 2: What strategy formulation framework is suitable for the formulation and implementation of competitive strategies by Jordanian private universities?

\subsection{Scope and Limitation}

\section{Difficulties encountered in administering the questionnaire:}

Ease of Accessing Respondents: While carrying out the study it was difficult to find personnel at most of the private universities in the study who were willing to participate in the survey. This may be due to the sensitivity of the questions in the survey and due to the potential respondent's need to maintain a neutral stand.

Dishonest Respondents: Secondly, respondents who participated in the study were not honest with some of their responses. This was noticed in just a few responses and it may imply that such respondents were suspicious of the research intentions even after repeatedly assuring them that their privacy will be respected and even after excluding their personal details from the study. 


\section{Difficulties and limitations during the research process:}

Limitations based on sample size: only 5 private universities were included in this study and the reliability of small sample sizes may limit the potential for generalizing the findings.

Sample population limitations: only top level managers were included in the in the survey and results could be limited due to the vested interests of these individuals in protecting the reputation and the image of their universities

\section{Methodology}

This section comprises a description of the methods by which the studies will be undertaken. The section describes documents (data) which will be used in this study, and procedures through which they were obtained, verified, and analyzed.

The objectives of this Study are to confirm (or refute) findings of a content analysis of published strategic plans of universities, and to extend insights into current competitive strategy of both universities as a precursor to the development of a model to guide competitive behavior in the higher education sector. Case studies are presented and interpreted, and findings outlined and assessed.

the content of the three major strategic documents of Jordanian private universities which participated in this study and which represents Jordan's private universities. However, A review reveals issues of long term and short term, to private universities. A total of 50 strategic issues were identified in the strategic statements of universities combined. Due to the fact that some of these issues reoccurred or were common to the individual strategic statements of both universities, I sifted through them and was able to isolate a total of 30 independent strategic issues. In line with the objective of this study, we analyzed the occurrence of competition related issues, to estimate the level of awareness and of commitment to improving their local and international competitive position. In doing so we were able to isolate only 8 strategic issues related to competition. A summary of these issues are presented below.

\section{Summary of Competition Related Strategic Issues Contained Statements Reviewed}

Competition Related Strategic Issues Contained in the Strategic Statements

1. The provision of quality education

2. Commitment to scientific research

3. The achievement of quality standards and accreditations

4. The improvement of infrastructure and Facilities that meets international standards, in order to attract regional and international students

5. To attain local prominence

6. To adhere to international standards on curricula and teaching

7. To diversify the universities financial resources

8. To develop its human resources.

\section{Previous Study}

The role of heads of department in the strategic management of educational institutions has attracted the attention of educational researchers only comparatively recently (e.g. Floyd and Wooldridge, 1996, Gold, 1998).

One key choice in strategic planning is the decision whether the central plan is created and translated into more localized planning in departments or whether strategic planning is an amalgam of subunit development plans

Although disparaged by some influential critics - especially Mintzberg (1994) who contended that the very term strategic planning was oxymoronic in that strategy must be crafted during operations rather than planned before them, and that business managers needed to be flexible enough to change their business strategies quickly in response to changing circumstances in the business environment - strategic management and planning practices have been widely adopted by private sector organizations since the early 1970s. Proponents claim that the practice of strategic management encourages management to think ahead systematically, forces the company to sharpen its objectives and policies, leads to better coordination of company efforts, and provides clearer performance standards for control Kotler (2000).

Although universities and related institutions were generally slower than other sectors of the economy in the adoption of strategic management and planning practices, they now widely accepted them in the institutional sector ( Katz, 1999b; Scott, 1999, 2003). While Anderson et al. (1999) pointed out that it was unreasonable to expect universities to adopt planning practices developed for the private sector uncritically - in as much as universities are unique institutions composed of faculties and schools with differing intellectual traditions, roles and objectives - strategic management and planning have been warmly embraced by institutions in the higher education sector for over 25 years (Howell et al., 2003; Legge, 2002; Schafer et al., 2005). In increasingly 
challenging environments, universities have looked to private models in strategic management, albeit with appropriate adaptation, to guide strategy development (Coaldrake \& Stillman, 1997; Katz et al., 1999a; Malony, 2000; Marginson \& Considine, 2000).

More than three decades ago, Doyle and Lynch (1976) argued that strategic management and planning by institutions of higher education was a planned response to the needs of students within a competitive environment. Urging universities to become more outward-looking, Thomas (1980) recommended that universities establish long-term review bodies to reconcile and optimize the diversities of strengths and interests of academics with those of communities they serve, to develop and sustain these processes by involving staff and students in future developments, and to not only monitor external environments but to influence them by continual advice and interaction. Defining strategic management as the process of developing and maintaining a strategic fit between organizations and their ever-changing marketing opportunities, Kotler and Murphy (1981) maintained that universities, usually efficient in areas of budgeting, scheduling and other short-range tactics, paid too little attention to long-range planning. Shirley (1983) suggested that strategic planning in universities should be concerned with six variables: mission, target groups of clientele, institutional goals and objectives, programs and services offered, geographical scope of operations, and the comparative advantage sought over institutions engaged in similar activities. Contending that universities have been slow to adapt to environmental changes.

More recently, Petrides (2003) argued that implementation of strategic planning processes in higher education institutions can break down information silos, increase collaboration among units, streamline work processes, and provide greater access to both academic and operational information. Howell et al. (2003) identified trends that affect distance learning programs, urging that these be taken into account in strategic planning processes in higher education settings. Arguing that managerial approaches are more likely to create highly insecure environments, Allen (2003) concluded that more sophisticated approaches to strategic planning were required in higher education institutions. Rowley and Sherman $(2001,2004)$ contended that in this new age of globally available real-time information, strategic planning has become increasingly more essential for institutions of higher education.

The role of heads of department in the strategic management of educational institutions has attracted the attention of educational researchers only comparatively recently (e.g. Floyd and Wooldridge, 1996, Gold, 1998).

One key choice in strategic planning is the decision whether the central plan is created and translated into more localized planning in departments or whether strategic planning is an amalgam of subunit development plans

\section{Hypothesis Development}

It is important to note the role of generic strategy formulation among firms. Generic strategies- a concept developed by Porter (1980) states that all firms irrespective of industry will develop strategies which falls into any of these three categories: cost leadership, differentiation and focus strategies. As the name implies, cost leadership strategy is one in which the adopting firm aims to be the leading organization which provides customers with quality products or services at the cheapest rate in the market. This kind of firm does this by focusing on production or service efficiencies which enable it reduce cost of production and eventually the price offered to customers. Differentiation strategy is one in which the adopting firm seeks to present itself as a provider of unique products or services in certain areas which provide customers with high value and for which they (customers) are willing to pay a premium price (Johnson, Whittington \& Scholes, 2012). Focus strategies on the other hand, is a type of strategy which targets just a niche group of customers within a larger market population, providing them only the mix of products or services which members of that niche demand and excluding services or products which they do not demand (Porter, 1980). According to Johnson, Whittington \& Scholes, (2012) two variants of focus strategies exist: cost-focus strategy and differentiation-focus strategy, implying that a particular firm's focus strategy may be based on meeting the price needs of a particular segment of the larger market or its differentiation needs but not both. In line with the above discussion, the first hypothesis I pose here in relation to

\subsection{Hypothesis 1}

The most suitable strategy formulation framework for private universities will be one which meets Shirley's (1983) six variables listed above.

Also, with regard to research question 2, Petrides (2003) noted that the most appropriate strategy implementation framework for universities is one which allows for easy communication and collaboration among units, allowing the streamlining of wok processes, self-management and accountability. In line with this, I propose the forth hypothesis thus: 


\subsection{Hypothesis 2}

The most suitable strategy implementation framework for private universities in Jordan, will be ones which allows for easy communications and collaborations on one hand and allows for the streamlining of work processes, self-management and accountability on the other.

\section{Summary}

In section four we present the research methodology where a brief explanation on how these hypotheses will be tested will be made.

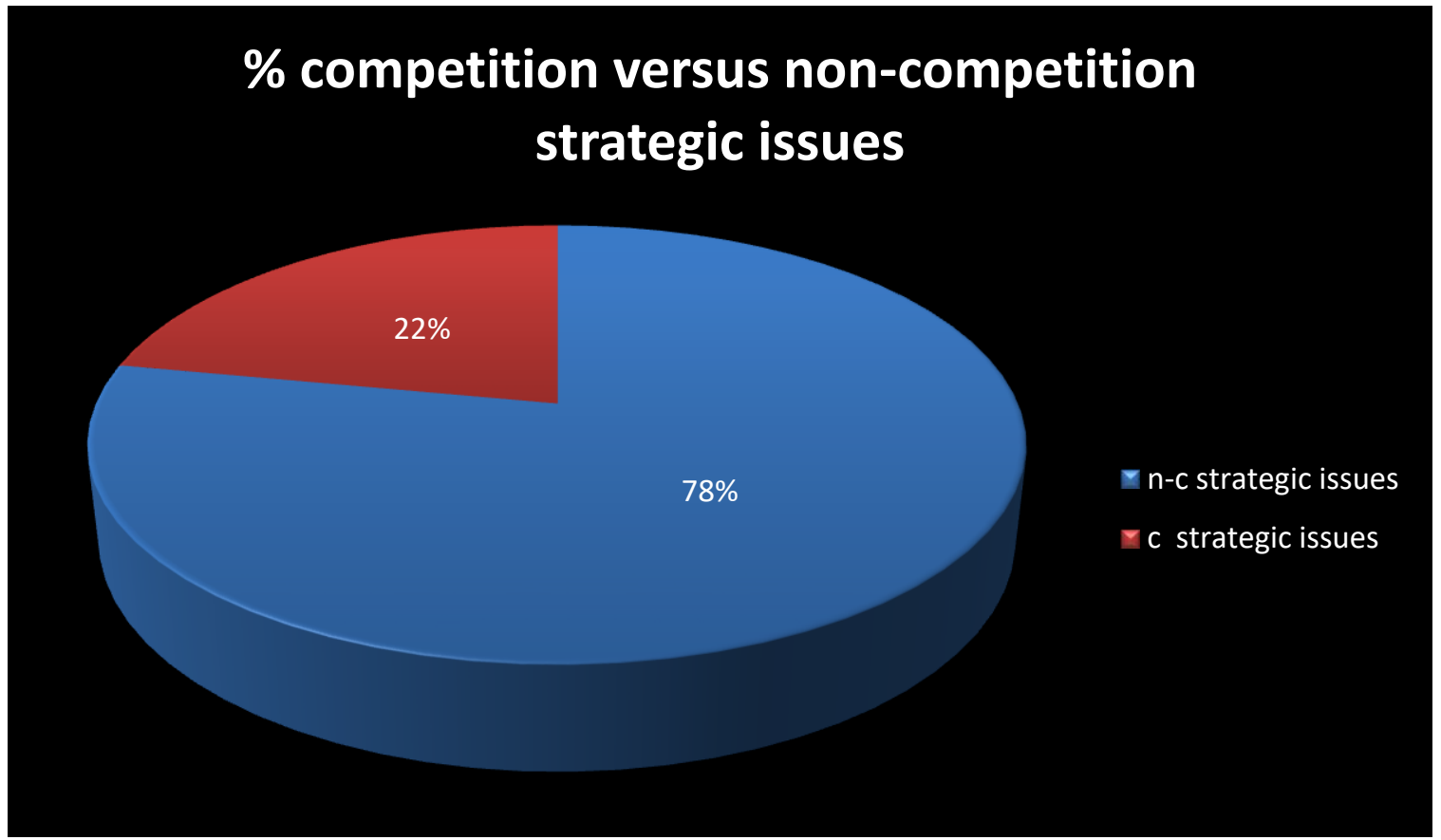

From the above table and chart, it can be seen that very little attention is paid by Jordanian private universities to issues of competition. $28 \%$ of all strategic issues contained in their strategic statements are competition related, while $72 \%$ are not competition related. This by itself tells very little, until we examine the nature of the competition related strategic issues themselves in the prior table. It shows that all of the competition related issues are ones which are general in nature- with no clear cut pattern for their attainment, and secondly, most of them are aimed at conforming to internationally accepted best-practices and standards. None of them is however novel or radical in nature, in that none of them seems to have targeted a niche market, nor adopted any of the generic strategies of service differentiation, cost leadership or focus strategy. It is clear at this stage that Jordan's private universities may be ill equipped to compete favorably with their regional and international counterparts in the ever increasing competitive global higher education sector.

\section{Findings:}

H1: The most suitable strategy formulation framework for private universities will be one which meets Shirley's (1983) six variables.

In all of the brief and extended strategic statements of the both universities analyzed, none showed any hint as to the actual strategy formulation procedure used during the crafting of their individual strategies. This may be as a result of owner interference in the strategy formulation process, adhoc and impromptu decision making processes or a simple case of the non-existence of such procedures. All in all study finds no support for hypothesis 1.

the study reveal that with regard to the suggestions for a suitable strategy formulation framework, only one of the recommended items in hypothesis 1 was recorded .Out of the six variables mentioned in this hypothesis .only the variable which recommended the participation of all relevant staff in the strategy formulation process was supported. In particular, content 13 (participation of employees in formulating and executing strategies) and content 12 (selecting leaders able to prepare and execute strategy); were the only two response categories which supported hypothesis 1 . Thus like the study finds no support for hypothesis 1 . 
To summarize, this study find no support for hypothesis. Based on these findings, I reject hypothesis 1and accept its null hypothesis.

H2: The most suitable strategy implementation framework for both universities in Jordan, will be ones which allows for easy communications and collaborations on one hand and allows for the streamlining of work processes, self-management and accountability on the other.

As with hypothesis 1, the study found no provisions for a systematic implementation of strategies developed in the entire brief and extensive strategy statements analyzed. Thus much like hypothesis 1 , the study finds no support for hypothesis 2 .

The study found mention of important strategy implementation variables mentioned in hypothesis 2 . For example in response to part 6 question 1 of the questionnaire administered, the managers mentioned that a suitable strategy implementation framework must enable the adoption of accountability (content 3), the empowerment of the academic leadership at the universities (content 7), providing continuous feedback on the execution of strategies (content 11); and the enhancement of creativity (content 18). Although it seems that these responses meet most of the criteria listed in the hypothesis, it was however noted that only two out of the five universities (40\%) mentioned contents 3 and 7; while only one out of the five universities (20\%) each mentioned contents 11 and 18. Thus all in all these and other criteria listed in hypothesis 2 were only present in at most $40 \%$ of the sample and was absent from the response of $60 \%$ of the sample studied. Thus I conclude that this study finds a very weak support for hypothesis 2 .

To summarize, the non-existence of any form of support for hypothesis 2 in this study which I conclude that all in all, find insignificant support for hypothesis 2 , and I thus reject hypothesis 4 and accept its null hypothesis.

\section{Result}

In this subsection, I present a very brief summary of other findings not directly related to the four hypothesis posed above, but of equal importance and worthy of highlighting. With regard to the preparedness and commitment of private universities in Jordan to meet the rising trend of competition in the higher education sector all around the world, study showed that they were not prepared as very little attention was paid to strategic issues related to competition. It was noted that of all the 29 strategic issue categories isolated from the content analysis of their strategic statements only $28 \%$ (8) of them were competitive strategy issues. This is a worrisome development and it means that Jordanian private universities are ill equipped to meet present and future challenges in the global higher education market. This may also explain the collective low performance of Jordan's private universities not only in Jordan and the Arab region, but when compared to other international universities around the world.

\section{References}

Allen, D. K. (2003). Organisational climate and strategic change in higher education: organisational insecurity. Higher Education, 46(1), 61-92. https://doi.org/10.1023/A:1024445024385

Altbach, P. G., \& Knight, J. (2005). The internationalization of higher education: motivations and realities, in The NEA 2006 Almanac of Higher Education. Washington D.C.: National Education Association.

Anderson, D., Johnson, R., \& Milligan, B. (1999). Strategic Planning in Australia Universities. (DETYA Evaluations and Investigations series). Canberra: AGPS.

Coaldrake, O. P., \& Steadman, L. (1998). On the Brink: Australia's Universities Confronting their Future. St. Lucia: University of Queensland Press.

Cooper, L., \& Wade, P. (2005). Profit and invest well, or perish. Australian, 29 June, 42.

Dess, G. G., \& Davis. P. S (1984). 'Porter's (1980) generic strategies as determinants of strategic group membership and organizational performance', Academy of Management Journal, 27(3), 467-488. https://doi.org/10.2307/256040

Dyson, R. G. (2004). Strategic development and SWOT analysis at the University of Warwick. European Journal of Operational Research, 152, 631-640. https://doi.org/10.1016/S0377-2217(03)00062-6

Floyd, S., \& B. Wooldridge (1996), The Strategic Middle Manager, New York, Jossey-Bass.

Hicks, D. (2012). Performance-based university research funding systems. Research Policy, 41(2), 251-261. https://doi.org/10.1016/j.respol.2011.09.007

Howell, S. L., Williams, P. B., \& Lindsay, N. S. (2003). Online Journal of Distance Learning Administration. 6 (3), Fall. (www.westga.edu/ distance/ojdla/fall63/howell63.html, accessed 22 May. 2012. 
Johnson, G., Scholes, K., \& Whittington, R. (2012). Exploring Corporate Strategy. 8thEdition. FT-Prentice Hall.

Katz, R. N., \& Associates. (1999a). Dancing with the Devil: Information Technology and the New Competition in Higher Education. San Francisco: Jossey-Bass.

Kotler, P., \& Murphy, P. E. (1981). Strategic planning for higher education. Journal of Higher Education, 52(5), 470-489. https://doi.org/10.2307/1981836

Kotler, P., Brown, L., Adam, S., Burton, S., \& Armstrong, G. (2007). Marketing. 7th edition. Sydney: Pearson Education.

Lane, B. (2006). Stiff competition for our scholarly fellows. Australian, 17 May.

Legge, I. (2002). Strategic and tactical planning in higher education: an overview of theory and issues with emphasis on research planning. Conference paper, 4th National Conference of Australian Network for Higher Education Policy Research (ANHEPR), Canberra, 7-8 December.

Malony, J. (2000). Australian universities today, in Coady, T. Why Universities Matter. Sydney: Allen \& Unwin

Marginson, S., \& Considine, M. (2000). The Enterprise University: Power, Governance and Re-invention in Australia. Sydney: Cambridge University Press.

Meek, V. L., \& Wood, F. Q. (2001). Governance and management, in National Report on Higher Education in Australia 2001 (DEST). Canberra: AGPS.

Mintzberg, H. (1994). The Rise and Fall of Strategic Planning. New York: Free Press.

Petrides, L. A. (2003). Strategic planning and information use: the role of institutional leadership in the community college. On the Horizon, 11(4), 10-14. https://doi.org/10.1108/10748120310508037

Pick, D. (2006). The re-framing of Australian higher education. Higher Education Quarterly, 60(3), 229-241. https://doi.org/10.1111/j.1468-2273.2006.00319.x

Porter, M. E. (1980). Competitive Strategy: Techniques for Analyzing Industries and Competitors. Free Press: New York.

Porter, M. E. (1985). Competitive Advantage: Creating and Sustaining Superior Performance. Free Press: New York.

Rood, D. (2006). Melbourne Uni lures high-profile staff. Age, 16 January.

Schafer, A., Tomasik, J., \& Gilmore, T. (2005). Crafting an effective strategic plan for a department of medicine. The American Journal of Medicine, 118(3), 315-320. https://doi.org/10.1016/j.amjmed.2005.01.002

Scott, P. (2005b). Cross-border higher education and internationalization: overview of concepts, trends and challenges. Keynote address at IAU International Conference, Alexandria, Egypt, 15-16 Novembe.

Webometrics Top 100 arab Universities Ranking. (2012) Retrieved 4th June, 2012. http://www.webometrics.info/top100_continent.asp?cont=aw

\section{Copyrights}

Copyright for this article is retained by the author(s), with first publication rights granted to the journal.

This is an open-access article distributed under the terms and conditions of the Creative Commons Attribution license (http://creativecommons.org/licenses/by/4.0/). 